\title{
Analisis Usability Sistem Komputerisasi Haji Terpadu Palembang Menggunakan Metode System Usability Scale (SUS)
}

\author{
Abdurrahman \& Maria Ulfa \\ Fakultas Teknik Ilmu Komputer, Universitas Bina Darma \\ Email: rahmannn448@gmail.com
}

\begin{abstract}
The Palembang Integrated Hajj Computerized System which is currently used as an information system for Hajj and Umrah pilgrims, because the entire data processing process for the purpose of making Hajj documents such as passports, departure and return flights, banking and biodata of prospective pilgrims refers to the integrated computer system. Both internally and externally there has never been an evaluation, either at the time of design, manufacture or implementation. This research was conducted with the title "Usability Analysis of the Palembang Integrated Hajj Computerized System Using the System Usability Scale (SUS) Method". Aims to measure the level of usefulness of the Palembang Siskohat Application and test the validity and reliability using SPSS 24. System Usability Scale (SUS) With 16 questions as a benchmark for assessing the application. 30 respondents were selected among the administrative staff of the Hajj and Umrah pilgrims in Palembang. The results of the usability test showed the value of Learnibilty 4.68, Efficiency 4.46, Memorabilty 4.64, Error 3.34 Satisfaction 3.74, the average usability value was expressed by Very good reliability and validity on each variable indicate that the questionnaire for each variable has a fairly good level of reliability.
\end{abstract}

Keyword : Siskohat, Analysis, Usability, System Usability Scale

\section{Pendahuluan}

Teknologi informasi dan komunikasi telah menjadi bagian yang sangat penting dan tidak terpisahkan dalam kehidupan di era glogalisasi modern saat ini, Perangkat hardware dan software yang telah digunakan sebagai pendukung dalam pengelolaan data pada instansi pemerintah.Adapun yang dimaksud dengan

Teknologi Informasi adalah suatu teknologi yang digunakan untuk mengolah data, termasuk memproses, mendapatkan, menyusun, menyimpan, memanipulasi data dalam berbagai cara untuk menghasilkan informasi yang berkualitas, yaitu informasi yang relevan, akurat dan tepat waktu, yang digunakan untuk keperluan pribadi, bisnis, dan pemerintahan dan merupakan informasi yang strategis untuk pengambilan keputusan. Peluang ini yang dimanfaatkan oleh pemerintah dalam memberikan informasi mengenai informasi haji, maka pemerintah meluncurkan Sistem Komputerisasi Haji Terpadu (Siskohat) Lahirnya Siskohat merupakan jawaban dari permasalahan yang terjadi pada tahun 1990 yaitu terjadinya peristiwa Mina yang menewaskan631 jemaah Haji Indonesia. Dan untuk pertama kalinya taun 1995 terjadi overkuota yang menimbulkan waiting list Setelah ada sistem yang memberikan informasi kepada masyarakat maka pemerintah dituntut untuk memberikantrasparansi. Oleh karena itu, Siskohat sangat penting untuk mengelola berbagai data yang berkaitan dengan ibadah haji, dan menyimpannya dengan rapi dan aman sehingga akan mempermudah dalam pencarian data dan juga akan terjaga dari hilangnya berbagai data penting ( Rosadi,A,2011).

Pada penelitian ini, Aplikasi Siskohat Palembang dijadikan sebagai objek penelitian yang diharapkan dapat ditemukan kelemahan ataupun kekurangan dari Aplikasi Siskohat palembang terutama dari aspek kegunaan. Aplikasi Siskohat Palembang yang saat ini digunakan sebagai pengelolaan data yang berkaitan dengan ibadah haji dilakukan evaluasi, baik pada saat 
perencanaan, desain atau implementasi. Analisis kegunaan terhadap Aplikasi Siskohat palembang merupakan langkah awal untuk menilai keberhasilan pelaksanaan impelementasi aplikasi, Banyak pendekatan yang bisa dilakukan dalam melakukan evaluasi, salah satunya adalah analisis Usability. Analisis Usability siskohat dilakukan untuk mengukur sejauh mana tingkat kegunaannya bagi pengguna. Proses analisis dengan mengumpulkan pendapat dari berbagai pihak mengenai fungsionalitas aplikasi.

Usability digunakan untuk mengukur tingkat kegunaan suatu sistem ataupun peralatan. Menurut International Organization For Standardization- ISO 9241- 11:1998 disebutkan bahwa Usability adalah tingkat kegunaan suatu produk yang dapat digunakan oleh pengguna untuk mencapai tujuan yang ditentukan secara efektif, efisien, dan memberikan kepuasan. Usability merupakan konsep yang menitikberatkan pada pembuatan sistem yang mudah dipelajari dan digunakan. Usability adalah hal yang sangat penting dalan desain interaksi yang meliputi: Perilaku, efisiensi, efektifitas, fleksibilitas, keamanan, untilitas, kemudahan dipelajari, dan kemudahan diingat. Salah satu metode yang dapat digunakan untuk melakukan analisis tingkat kegunaan aplikasi adalah System Usability Scale (SUS) adalah salah satu metode uji pengguna yang menyediakan alat ukur yang "quick and dirty" yang dapat diandalkan.Metode uji pengguna ini diperkenalkan oleh John Brooke pada tahun 1986 (Thomas, 2015) yang dapat digunakan untuk melakukan analisis berbagai jenis produk atau layanan, termasuk di dalamnya Hardware, Software, perangkat Mobile, Website, dan Aplikasi. Metode uji pengguna inilah yang digunakan dalam mengevaluasi adengan aplikasi siskohat.

\section{Tinjauan Literatur}

System Usability Scale (SUS) adalah salah satu metode uji pengguna yang menyediakan alat ukur yang "quick and dirty" dan dapat diandalkan. Diaplikasikan dengan menggunakan pertanyaan berbentuk kuesioner yang diikuti dengan 5 opsi jawaban untuk setiap pertanyaan, mulai dari Sangat Setuju hingga Sangat Tidak Setuju. Metode uji pengguna diperkenalkan (John Brooke, 1986) yang dapat digunakan untuk mengevaluasi berbagai jenis layanan yang ada pada Siskohat.

System Usability Scale (SUS) merupakan metode pengujian usability suatu sistem secara sederhana dengan sepuluh skala yang memberikan pandangan secara menyeluruh dari evaluasi tujuan kebergunaan. SUS merupakan skala Likert yang sederhana dengan responden diharuskan penjawab tingkat kesetujuan dan ketidaksetujuan dalam skala 5 atau 7 poin. SUS dapat dipercaya, skala usability dengan biaya rendah yang dapat digunakan untuk pengujian sistem usability scara global. (Brooke, 2007).

System Usability Scale (SUS) menggunakan kuesioner dengan skala Likert guna mengukur grade usability dari sistem, dibuat oleh John Brooke, hasil kuesioner SUS dengan nilai antaranya 0 hingga 100, dimana 100 menjadi indicator usability terbaik, setelah diketahui skor rata-rata, kemudian dibandingkan dengan range nilai yang dikemukakan oleh Souro (2011).

SUS telah menjadi standar industry, dengan referensi di lebih dari 1.300 artikel dan publikasi. Manfaat penting penggunaan SUS termasuk :

a. Skala yang sangat mudah untuk diberikan kepada peserta

b. Dapat digunakan pada ukuran sampel kecil dengan hasil yang diandalkan. 
c. Apakah Valid- dapat secara efektif membedakan antara sistem yang dapat digunakan dan tidak dapat digunakan.

d. Usability Testing untuk mengetahui kualitas dari perangkat yang dibuat. Metode yang digunakan untuk mengukur usability tersebut adalah dengan System Usability Scale (SUS).

e. Metode ini digunakan karena dapat menggunakan contoh yang tidak terlalu besar. Pada metode ini menggunakan kuesioner yang terdiri dari berapa pertanyaan.

f. Pada penelitian yang akan dilakukan, peneliti melakukan percobaan dengan cara memberi perlakuan terhadap SUS yang dibuat oleh John Brooke perlakuan yang dimaksud adalah menambahkan alasan pada setiap pernyataan, di mana alasan-alasan tersebut diambil dari usability Nielsen. Percobaan ini didasarkan atas keingintahuan peneliti terhadap adanya hubungan kausalitas antara SUS yang tidak diberi perlakuan dengan SUS yang diberi perlakuan. Peneliti memiliki hipotesis, penggunaan metode SUS yang tidak diberi perlakuan dengan metode SUS yang diberi perlakuan akan diperoleh hasil yang berbeda secara signifikan. Hal ini disebabkan karena adanya kesamaan persepsi diantara pengguna terhadap setiap pernyataan.

g. Alasan-alasan yang diajukan untuk mendukung setiap pernyataan, peneliti ambil dari 5 aspek usability Nielsen kemudian dikaitkan dengan setiap pernyataan dari John Brooke. Dengan demikian, pengguna akan lebih mudah memahami pernyataan dan ada kesamaan persepsi terhadap metode SUS.

Penentuan pertama dilihat dari sisi tingkat penerimaan pengguna, grade skala dan adjektif rating yang terdiri dari tingkat penerimaan pengguna terdapat tiga kategori yaitu not acceptable, marginal dan acceptable. best imaginable.

Penentuan yang kedua dilihat dari sisi percentile range (SUS skor) yang memiliki grade peniliaian yang terdiri dari A,B,C,D dan F.

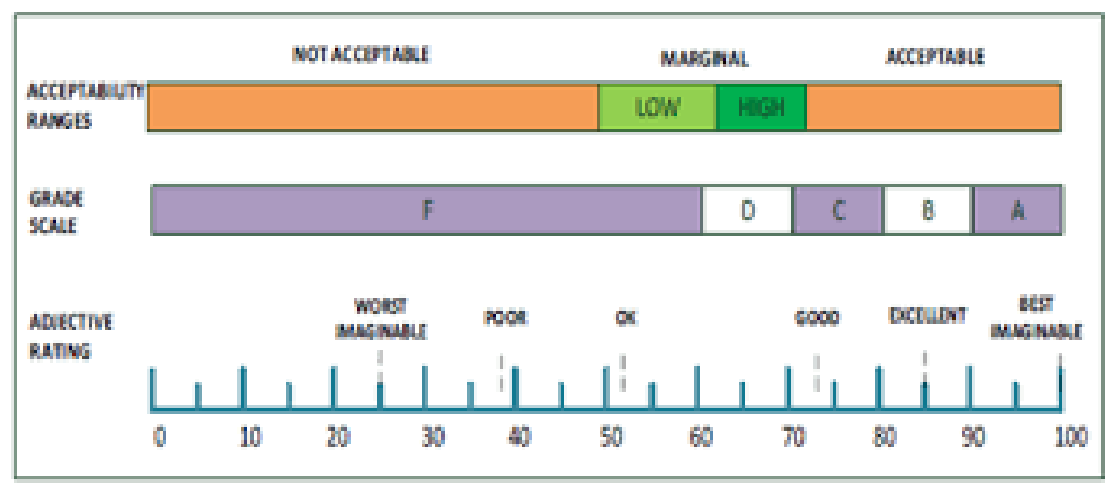

Gambar 2. 1 Penentuan Hasil Penelaian

(Bangor,A., Kortum, P., \& Miller, J.: 2009)

Penentuan hasil penilaian dengan cara SUS score percentile rank memiliki perbedaan dengan cara penilaian acceptablelty, grade scale, adjective rating. Perbedaan yang terjadi pada kategori penilaian, pada SUS skor percentile rank dilakukan perbandingan hasil penilaian pengguna secara umum sedangkan pada acceptableity, grade scalel adjective rating dibedakan kedalam tiga kategori. 


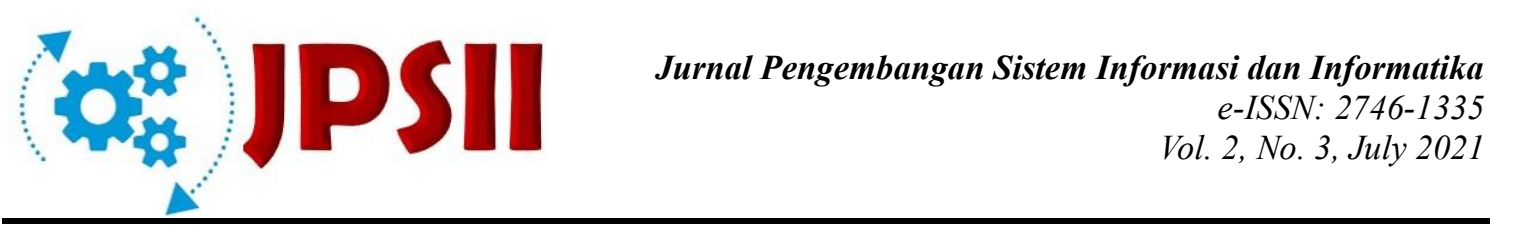

Adapun penelitian terdahulu yang menjadi acuan penulis untuk melakukan penelitian ini yaitu :

Penelitian yang dilakukan oleh Rifka Arlenia Putri dan Imamulhakim Syahid Putra, dengan judul "Analisis Usability Pada Aplikasi Belido.id Menggunakan Metode System Usability Scale (SUS)" Berdasarkan penelitian, Belido.id merupakan salah satu online marketplace yang memberikan kesempatan kepada seluruh masyarakat untuk melakukan transaksi jual beli secara online dengan berkonsentrasi pasar sumatera khususnya sumatera bagian selatan yang mendapatkan support dari AIESEC. Dalam memberikan layanan Belido.id pasti ingin memberikan pelayanan yang terbaik, pihak Belido.id tidak ingin mengecewakan para pengguna dikarenakan aplikasi yang sulit digunakan sehingga mengakibatkan pengguna gagal dalam mencari informasi atau gagal dalam aktivitas jual beli. Untuk mendapatkan produk yang sesuai dengan kebutuhan, baik dari segi desain tampilan maupun sistem yang digunakan, tentunya perlu dilakukan analisis terkait usability produk. Tujuan dilakukannya penelitian ini adalah Untuk menjamin perangkat lunak Belido.id ini layak untuk digunakan oleh pengguna atau tidak, maka dilakukan pengujian usability terhadap apilkasi Belido.id menggunakan metode pengujian System Usability Scale (SUS). Pengujian ini menggunakan 10 pernyataan sebagai tolak ukur penilaian. Dengan responden sebanyak 80 orang. Hasil dari pengujian usability aplikasi Belido.id dengan metode SUS ini memperlihatkan hasil akhir penelitian pada pengujian melalui kuisioner sebesar 61,5 berada di grade D yang berarti aplikasi Belido.id masih memiliki sedikit kesulitan atau adanya kendala saat menggunakan aplikasi ini.

Penelitian yang dilakukan oleh Ida A G R W Astari dan I Nyoman T Putra, dengan judul "Analisis Sistem Informasi Kemdikbud Pada SD Negeri 2 Dawan Klod Dengan System Usability Scale" Berdasarkan Penelitian, Pada era 4.0 ini dimana teknologi semakin canggih, dan sangat cepat perkembanganya, teknologi saat ini sangat membantu dalam bidang bisnis, kedokteran, industri hingga dunia pendidikan, di dunia pendidikan sangat di perlukan sistem informasi. Apalagi pada saat pandemi seperti ini sangat dibutuhkan informasi pada setiap sekolah untuk membantu siswa-siswi mengetahui informasi yang berada di sekolah. Pemerintah Indonesia menyediakan sistem informasi kemdikbud untuk mengetahui informasi semua sekolah yang ada di Indonesia dengan alamat website http://sekolah.data.kemdikbud.go.id. Rendahnya informasi yang didapatkan tentang sekolah di Indonesia salah satunya informasi di Sekolah Dasar Nergeri 2 Dawan Klod, masih banyak informasi yang belum diupdate maka perlu dilakukan pengujian usability menggunakan metode SUS (System Usability Scale) dengan 10 pertanyaan sebagai tolak ukur kualitas sistem kemdikbud. Sebanyak 50 responden secara acak ikut berpartisipasi dalam penelitian ini. Hasil pengujian menunjukkan skor SUS (System Usability Scale) berada pada skor 49,9 yang berarti sistem kemdikbud sangat kurang. Ini menunjukkan bahwa sistem informasi kemdikbud belum dapat diterima oleh masyarakat dan diperlukannya perbaikan agar dapat mencapai nilai Excellent yang skornya diatas 80 . Penelitian ini dilakukan untuk mengetahui aspek-aspek usability pada sistem tersebut bagaimana efektivitas, efisiensi, dan kepuasan pengguna untuk mengetahui kulitas sistem kemdikbud. Dan dapat meningkatkan mutu sekolah SDN 2 Dawan Klod dari sudut pandang sekolah lain yang berada di Kabupaten Klungkung.

Penelitian yang dilakukan oleh Usman Ependi, Febriyanti Panjaitan, dan Hutrianto, dengan judul "System Usability Scale AntarMuka Palembang Guide Sebagai Media Pendukung Asian Games XVIII" berdasarkan Penelitian, Palembang Guide merupakan perangkat lunak penyedia informasi sarana pendukung pelaksanaan Asian Games XVIII 
yang berisikan informasi venue olahraga, fasilitas transportasi, objek wisata, restoran, toko (mall), hotel, tempat pengisian bahan bakar, fasilitas kesehatan, pos kemanan, kantor pemerintahan dan institusi pendidikan. Perangkat lunak ini dikembangkan sesuai dengan instruksi presiden Republik Indonesia tentang persiapan pelaksanaan Asian Games tahun 2018. Untuk menjamin perangkat lunak Palembang Guide layak untuk digunakan oleh pengguna akhir maka dilakukan pengujian antarmuka menggunakan instrumen system usability scale (SUS). Pengujian antarmuka dengan instrumen SUS telah dilakukan secara terstruktur dan terukur secara akurat menggunakan 10 pernyataan sebagai tolak ukur penilaian. Hasil pengujian antarmuka perangkat lunak Palembang Guide dengan instrumen SUS memperlihatkan skor penilaian berada pada angka 83 yang berarti perangkat lunak Palembang Guide dinyatakan dapat diterima (acceptable) dantermasuk dalam grade A dan B dengan rating excellent. Dengan demikian perangkat lunak Palembang Guide dapat dijadikan salah satu alternative alat bantu bagi masyarakat dalam mencari tempat tempat sarana prasarana pendukung yang dibutuhkan berkaitan dengan Asian Games XVIII di Kota Palembang.

\section{Metode Penelitian}

Metode penelitian yang digunakan dalam penelitian ini adalah penelitian deskriptif.Menurut Sinulingga $(2011,23)$ yang dimaksud dengan penelitian deskriptif adalah Suatu jenis penelitian yang bertujuan untuk mendeskripsikan secara sistematik, faktual, dan akurat tentang fakta-fakta dan sifat-sifat suatu objek atau populasi tertentu.

\subsection{Waktu dan Tempat Penelitian}

Tempat penelitian dilakukan pada Kantor Kementerian Agama Palembang di Jl. Jenderal Ahmad Yani, 14 Ulu, Kec. Seberang Ulu II, Kota Palembang, Sumatera Selatan 30264, Penelitian ini memerlukan waktu kurang lebih 5 (lima) bulan dimulai Februari 2021 s/d juni 2021.

\subsection{Alat}

Penelitian ini menggunakan alat penelitian berupa perangkat keras dan perangkat lunak, yaitu :

1. Perangkat Keras (Hardwarea)

a.Laptop

b. Mouse

c.Printer

2. Perangkat Lunak (Software)

a. Sistem Operasi Windows 10

b. Mircrosoft Office 2010

c. SPSS

\subsection{Bahan}

Bahan Penelitian yang akan digunakan oleh penulis antar lain : 
1. Jurnal

2. E-Book / Buku

\subsection{Metode Pengumpulan Data}

Dalam pengumpulan data untuk mengukur usability sistem komputerisasi haji terpadu palembang digunakan beberapa cara, yaitu :

a. Wawancara (Interview)

Dalam metode ini penulis mengumpulkan data penelitian dengan bertanya langsung kepada pihak yang bersangkutan yang dapat memberikan informasi yang dibutuhkan.

b. Kuesioner

Pada metode ini yang dilakukan adalah membuat beberapa pertanyaan untuk melakukan uji ketergunaan agar mengetahui tingkat penerapan layanan dan tingkat kemudahan penggunaan sistem komputerisasi haji terpadu palembang.

c. Studi Pustaka

Yaitu dengan mempelajari, mencari dan mengumpulkan data yang berhubungan dengan penelitian seperti buku dan internet yang berkaitan tentang analisissistem komputerisasi haji terpadu palembang.

\section{Hasil dan Pembahasan}

\subsection{Hasil}

Berdasarkan hasil dari penelitian dengan menggunakan 5 variabel usability testing untuk mengukur penggunaan aplikasi siskohat pendaftaran haji, maka hasil dari usability sebagai berikut.

Tabel 4.1 Hasil 5 Variabel Usability

\begin{tabular}{|c|c|r|}
\hline Variabel & Jumlah Sampel & Rata-rata \\
\hline Learnability & 30 & 4,68 \\
\hline Efficiency & 30 & 4.46 \\
\hline Memorability & 30 & 4.64 \\
\hline Error & 30 & 3.34 \\
\hline & & \\
\hline
\end{tabular}




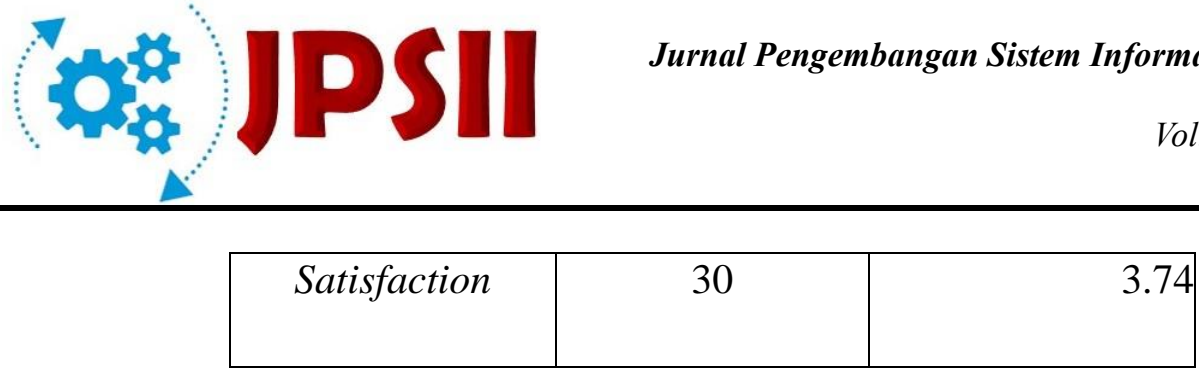

\subsection{Pembahasan}

Pada Tahap ini akan ditampilkan hasil pengumpulan data - data kuesioner berdasarkan hasil kuesioner terhadap para responden penggunaan aplikasi sistem komputerisasi haji terpadu (SISKOHAT) Palembang. Dalam hal ini jumlah kuesioner 30 responden kedalam 5 jenis variabel dan 15 pertanyaan, berikut adalah hasil rekap kuesioner yang telah di teliti oleh peneliti.

Tabel 4.2 Hasil Rakapitulasi Kuesioner

\begin{tabular}{|c|c|c|c|c|c|c|c|c|c|c|c|c|c|c|c|}
\hline No. & \multicolumn{3}{|c|}{ Learnability } & \multicolumn{3}{|c|}{ Efficiency } & \multicolumn{3}{|c|}{ Memorabilit } & \multicolumn{3}{|c|}{ Error } & \multicolumn{3}{|c|}{ Satisfaction } \\
\hline 1 & 5 & 5 & 5 & 5 & 5 & 5 & 5 & 5 & 5 & 2 & 3 & 3 & 4 & 5 & 5 \\
\hline 2 & 5 & 5 & 5 & 5 & 4 & 4 & 4 & 5 & 5 & 4 & 3 & 4 & 4 & 3 & 4 \\
\hline 3 & 5 & 5 & 5 & 5 & 5 & 5 & 5 & 5 & 5 & 2 & 4 & 3 & 4 & 3 & 4 \\
\hline 4 & 5 & 5 & 5 & 5 & 5 & 5 & 5 & 5 & 5 & 3 & 3 & 4 & 5 & 3 & 4 \\
\hline 5 & 5 & 5 & 5 & 5 & 4 & 5 & 4 & 5 & 4 & 5 & 4 & 5 & 4 & 3 & 4 \\
\hline 6 & 4 & 4 & 4 & 4 & 4 & 4 & 4 & 4 & 4 & 4 & 4 & 4 & 4 & 3 & 4 \\
\hline 7 & 4 & 4 & 4 & 4 & 5 & 4 & 4 & 4 & 4 & 4 & 4 & 4 & 5 & 2 & 5 \\
\hline 8 & 5 & 5 & 5 & 5 & 5 & 5 & 5 & 4 & 5 & 3 & 4 & 3 & 5 & 2 & 5 \\
\hline 9 & 4 & 4 & 4 & 4 & 5 & 5 & 5 & 5 & 5 & 4 & 4 & 3 & 5 & 2 & 5 \\
\hline 10 & 5 & 4 & 4 & 4 & 5 & 5 & 5 & 4 & 4 & 4 & 3 & 3 & 5 & 3 & 5 \\
\hline 11 & 5 & 5 & 5 & 5 & 5 & 5 & 5 & 5 & 5 & 3 & 3 & 3 & 4 & 3 & 4 \\
\hline 12 & 5 & 5 & 5 & 5 & 5 & 5 & 5 & 4 & 5 & 4 & 3 & 4 & 5 & 3 & 4 \\
\hline 13 & 5 & 5 & 5 & 5 & 4 & 4 & 4 & 5 & 5 & 4 & 3 & 3 & 4 & 2 & 4 \\
\hline 14 & 4 & 4 & 4 & 4 & 5 & 5 & 5 & 4 & 4 & 3 & 2 & 3 & 4 & 4 & 4 \\
\hline 15 & 5 & 5 & 5 & 5 & 5 & 5 & 5 & 5 & 4 & 3 & 3 & 4 & 4 & 4 & 5 \\
\hline 16 & 5 & 4 & 4 & 4 & 5 & 5 & 5 & 4 & 4 & 5 & 5 & 4 & 4 & 4 & 4 \\
\hline 17 & 5 & 5 & 5 & 5 & 4 & 4 & 4 & 4 & 4 & 2 & 3 & 2 & 5 & 4 & 5 \\
\hline 18 & 5 & 5 & 5 & 4 & 5 & 5 & 5 & 4 & 4 & 3 & 4 & 3 & 4 & 3 & 4 \\
\hline 19 & 5 & 5 & 4 & 4 & 4 & 4 & 3 & 4 & 4 & 3 & 2 & 2 & 5 & 3 & 3 \\
\hline 20 & 5 & 4 & 5 & 5 & 5 & 5 & 4 & 5 & 5 & 2 & 3 & 3 & 5 & 2 & 3 \\
\hline 21 & 5 & 5 & 4 & 5 & 5 & 5 & 3 & 5 & 5 & 3 & 3 & 3 & 5 & 2 & 2 \\
\hline 22 & 4 & 5 & 4 & 5 & 5 & 5 & 3 & 5 & 5 & 3 & 3 & 4 & 5 & 3 & 2 \\
\hline 23 & 5 & 5 & 4 & 5 & 5 & 5 & 2 & 5 & 5 & 2 & 2 & 2 & 5 & 2 & 2 \\
\hline 24 & 4 & 4 & 5 & 5 & 5 & 4 & 5 & 4 & 5 & 4 & 4 & 5 & 5 & 2 & 5 \\
\hline 25 & 5 & 5 & 4 & 4 & 4 & 5 & 5 & 5 & 5 & 4 & 4 & 5 & 4 & 2 & 5 \\
\hline 26 & 5 & 5 & 5 & 5 & 5 & 5 & 4 & 5 & 5 & 2 & 2 & 2 & 5 & 4 & 2 \\
\hline 27 & 5 & 5 & 5 & 5 & 5 & 5 & 2 & 5 & 5 & 2 & 2 & 2 & 5 & 4 & 2 \\
\hline 28 & 5 & 5 & 4 & 4 & 5 & 5 & 2 & 5 & 5 & 2 & 2 & 2 & 5 & 2 & 2 \\
\hline
\end{tabular}

Published by: 


\begin{tabular}{|l|l|l|l|l|l|l|l|l|l|l|l|l|l|l|l|}
\hline 29 & 5 & 5 & 5 & 5 & 5 & 5 & 2 & 5 & 5 & 3 & 3 & 2 & 5 & 2 & 2 \\
\hline 30 & 5 & 5 & 4 & 4 & 4 & 4 & 2 & 5 & 5 & 3 & 2 & 2 & 5 & 2 & 2 \\
\hline
\end{tabular}

\subsubsection{Analisis Data}

Skala pengukuran yang dilakukan yaitu dengan skala Likert dengan score 1-5. Adapun hasil penilaian respondent dari penyebaran kuesioner yang dilakukan, dengan pilihan jawaban yang diberikan yaitu, SS (Sangat Setuju), S (Setuju), N (Netral), TS (Tidak Setuju) dan STS (Sangat Tidak Setuju).

Tabel 4.3 Hasil penilaian responden

\begin{tabular}{|c|c|c|c|c|c|}
\hline \multirow{2}{*}{ No } & \multicolumn{5}{|c|}{ Learnbility } \\
\hline & STS & TS & $\mathbf{N}$ & S & SS \\
\hline 1 & 0 & 0 & 0 & 6 & 24 \\
\hline 2 & 0 & 0 & 0 & 8 & 22 \\
\hline 3 & 0 & 0 & 0 & 13 & 17 \\
\hline 4 & 0 & 0 & 0 & 11 & 19 \\
\hline \multirow{2}{*}{ No } & \multicolumn{5}{|c|}{ Efficiency } \\
\hline & STS & TS & $\mathbf{N}$ & $\mathbf{S}$ & SS \\
\hline 1 & 0 & 0 & 0 & 8 & 22 \\
\hline 2 & 0 & 0 & 0 & 8 & 22 \\
\hline 3 & 0 & 5 & 3 & 8 & 14 \\
\hline \multirow{2}{*}{ No } & \multicolumn{5}{|c|}{ Memorability } \\
\hline & STS & TS & $\mathbf{N}$ & $\mathbf{S}$ & SS \\
\hline
\end{tabular}

\begin{tabular}{|c|c|c|c|c|c|}
\hline 1 & 0 & 0 & 0 & 11 & 19 \\
\hline 2 & 0 & 0 & 0 & 10 & 20 \\
\hline \multirow{2}{*}{ No } & \multicolumn{5}{|c|}{ Error } \\
\hline & STS & TS & $\mathbf{N}$ & S & SS \\
\hline 1 & 0 & 8 & 11 & 9 & 2 \\
\hline 2 & 0 & 7 & 13 & 9 & 1 \\
\hline 3 & 0 & 8 & 11 & 8 & 3 \\
\hline \multirow{2}{*}{ No } & \multicolumn{5}{|c|}{ Satisfaction } \\
\hline & STS & TS & $\mathbf{N}$ & $\mathbf{S}$ & SS \\
\hline 1 & 0 & 0 & 0 & 12 & 18 \\
\hline 2 & 0 & 12 & 11 & 6 & 1 \\
\hline 3 & 0 & 8 & 2 & 11 & 9 \\
\hline
\end{tabular}

Berdasarkan Tabel 4.3, penilaian responden yang menunjukkan hasil rata- rata pemilihan kuesioner oleh responden penggunaan aplikasi Siskohat palembang, terlihat dominan terjadi di responden dengan Setuju dan Sangat Setuju.

\subsubsection{Uji Kualitas Data}


Kuesioner dikatakan valid apabila dapat mempresentasikan atau mengukur apa yang hendak diukur (variabel penelitian). Pengujian validitas dalam penelitian ini dilakukan dengan membandingkan antara $r$ hitung dengan $r$ tabel. $r$ hitung didapat dengan software SPSS. Nilai $r$ hitung setiap butir pertanyaan kemudian dibandingkan dengan nilai $r$ tabel untuk mengetahui valid atau tidaknya butir pertanyaan tersebut. Berikut ini adalah hasil pengujian validitas setiap aspek- aspek yang ada dalam usability :

1. Learnabilty

Hasil uji validitas untuk variabel learnability dengan menggunakan software SPSS dapat dilihat pada tabel 4.9 dibawah ini.

Tabel 4.4 Hasil Learnability Correlations

\begin{tabular}{|c|c|c|c|c|c|}
\hline & & $\begin{array}{c}\text { Learnabilit } \\
\text { y1 }\end{array}$ & $\begin{array}{c}\text { learnabilit } \\
\text { y2 }\end{array}$ & $\begin{array}{c}\text { learnabilit } \\
\text { y3 }\end{array}$ & $\begin{array}{c}\text { learnabilit } \\
\text { y4 }\end{array}$ \\
\hline \multirow{6}{*}{ learnabilit y2 } & & 1 & $.641^{* *}$ & $.404^{*}$ & .369 \\
\hline & & & .000 & .027 & .094 \\
\hline & & 30 & 30 & 30 & 30 \\
\hline & Pearson Correlation & $.641 * *$ & 1 & $.385^{*}$ & $.480 * *$ \\
\hline & Sig. (2-tailed) & .000 & & .035 & .007 \\
\hline & $\mathrm{N}$ & 30 & 30 & 30 & 30 \\
\hline \multirow{3}{*}{ learnabilit y3 } & Pearson Correlation & $.404^{*}$ & $.385^{*}$ & 1 & $.731 * *$ \\
\hline & Sig. (2-tailed) & .027 & .035 & & .000 \\
\hline & $\mathrm{N}$ & 30 & 30 & 30 & 30 \\
\hline \multirow[t]{3}{*}{ learnabilit y4 } & Pearson Correlation & .311 & $.480 * *$ & $.731 * *$ & 1 \\
\hline & Sig. (2-tailed) & .094 & .007 & .000 & \\
\hline & $\mathrm{N}$ & 30 & 30 & 30 & 30 \\
\hline
\end{tabular}

**. Correlation is significant at the 0.01 level (2-tailed).

*. Correlation is significant at the 0.05 level (2-tailed).

Berdasarkan Output diatas dapat diketahui angka r hitung untuk soal learnability 1 adalah 0,369 , yang kedua 0,480 , yang ketiga 0,731, dan yang terakhir adalah 1 . Maka dapat disimpulkan bahwa hasil pernyataan dari soal learnability 1-4 adalah Valid, karena berada diatas angka 0,3

Tabel 4.5 Hasil uji Reliabilitas Learnabiltiy Reliability Statistics

\begin{tabular}{r|r}
$\begin{array}{c}\text { Cronbach's } \\
\text { Alpha }\end{array}$ & N of Items \\
\hline .795 & 4 \\
\hline
\end{tabular}

Berdasarkan hasil pengujian reliabilitas diatas, diketahui angka cronbach's alpha adalah 
0,873, jadi angka tersebut lebih besar dari angka minimal cronbach 's alpha yaitu 0,6 oleh karena itu instrumen penelitian yang digunakan untuk mengukur kualitas aplikasi siskohat dapat dikatakan Reliabel atau Handal.

\subsubsection{Hasil Usability Testing}

Dari interpretasi hasil usability testing di atas, maka didapatkan rekap nilai usability dari masing-masing atribut atau variabel seperti pada tabel -tabel berikut di bawah ini.

1. Total nilai Learnability

Tabel 4.6 Total Nilai Learnability

\begin{tabular}{|c|c|c|c|c|c|}
\hline \multicolumn{7}{|c|}{ Learnbility } & Total \\
\cline { 1 - 3 } $\mathbf{1}$ & $\mathbf{2}$ & $\mathbf{3}$ & $\mathbf{4}$ & $\mathbf{5}$ & Nilai \\
\hline 0 & 0 & 0 & 24 & 120 & 144 \\
\hline 0 & 0 & 0 & 32 & 110 & 142 \\
\hline 0 & 0 & 0 & 52 & 85 & 137 \\
\hline 0 & 0 & 0 & 44 & 95 & 139 \\
\hline
\end{tabular}

Total nilai di atas didapatkan dari jumlah seluruh nilai dari sekala $1-5$

2. Total nilai Efficiency

Tabel 4.7 Total Nilai Efficiency

\begin{tabular}{|c|c|c|c|c|c|}
\hline \multicolumn{5}{|c|}{ Efficiency } & \multirow{2}{*}{$\begin{array}{l}\text { Total } \\
\text { Nilai }\end{array}$} \\
\hline 1 & 2 & 3 & 4 & 5 & \\
\hline 0 & 0 & 0 & 32 & 110 & 142 \\
\hline 0 & 0 & 0 & 32 & 110 & 142 \\
\hline 0 & 0 & 15 & 32 & 70 & 117 \\
\hline
\end{tabular}

Total nilai di atas didapatkan dari jumlah seluruh nilai dari sekala $1-5$

3. Total nilai Memorability

Tabel 4.8Total Nilai Memorability

\begin{tabular}{|c|c|c|c|c|c|}
\hline \multicolumn{7}{|c|}{ Memorability } & Total \\
\hline $\mathbf{1}$ & $\mathbf{2}$ & $\mathbf{3}$ & $\mathbf{4}$ & $\mathbf{5}$ & Nilai \\
\hline 0 & 0 & 0 & 44 & 95 & 139 \\
\hline \hline 0 & 0 & 0 & 40 & 100 & 140 \\
\hline
\end{tabular}

Total nilai di atas didapatkan dari jumlah seluruh nilai dari sakala 1-5

4. Total nilai Error

Tabel 4.9 Total Nilai Error

\begin{tabular}{|l|l|l|l|l|l|}
\hline \multicolumn{5}{|c|}{ Error } & \multirow{2}{*}{$\begin{array}{c}\text { Total } \\
\text { nilai }\end{array}$} \\
\hline 1 & 2 & 3 & 4 & 5 & \\
\hline 0 & 16 & 33 & 36 & 10 & \\
\hline 0 & 14 & 39 & 36 & 5 & \\
\hline 0 & 16 & 33 & 32 & 15 & \\
\hline
\end{tabular}

Total nilai di atas didapatkan dari jumlah seluruh nilai dari skala 1-5

Published by: 
5. Total Nilai Satisfaction

Tabel 4.10 Total Nilai Satisfaction

\begin{tabular}{|l|l|l|l|l|l|}
\hline \multicolumn{5}{|c|}{ Memorability } & \multirow{2}{*}{$\begin{array}{c}\text { Total } \\
\text { nilai }\end{array}$} \\
\hline $\mathbf{1}$ & $\mathbf{2}$ & $\mathbf{3}$ & $\mathbf{4}$ & $\mathbf{5}$ & \\
\hline 0 & 0 & 0 & 48 & 90 & 138 \\
\hline 0 & 24 & 33 & 24 & 5 & 86 \\
\hline 0 & 16 & 6 & 44 & 45 & 111 \\
\hline
\end{tabular}

Total nilai di atas didapatkan dari jumlah seluruh nilai dari skala 1-5

Setelah dijumlahkan total kuisoner dari responden, maka selanjutnya jumlah total masing-masing variabel dijumlahkan dan didapat nilai rata-rata yang selanjutnya per variabel di jumlahkan lagi lalu dibagi total jumlah soal masing- masing variabel. Nilai rata - rata di dapatkan dari total : jumlah responden (144/30) dan seterusnya.

Tabel 4.11 Tabel Rata-Rata

\begin{tabular}{|c|c|c|c|c|c|}
\hline Variabel & \multicolumn{4}{|c|}{ Nilai Rata - Rata } & Total Rata -Rata \\
\hline Learnability & 4.83 & 4.73 & 4.56 & 4.63 & 4.68 \\
\hline Efficiency & 4.73 & 4.73 & 3.93 & 0 & 4.46 \\
\hline Memorability & 4.63 & 4.66 & 0 & 0 & 4.64 \\
\hline Error & 3.16 & 3.13 & 3.22 & 0 & 3,34 \\
\hline Satisfaction & 4.63 & 2.86 & 3.73 & 0 & 3.74 \\
\hline
\end{tabular}

\section{Kesimpulan}

System Usability Scale dapat dijadikan sebagai alat pengukuran dalam melakukan penilaian interface perangkat lunak yang terukur dan terstruktur secara akurat. Memiliki beragam cara dalam menentukan penilaian seperti yang telah diperlihatkan ketika melakukan analisis aplikasi Sistem Komputerisasi Haji Terpadu (SISKOHAT).

Berdasarkan hasil dan pembahasan yang telah diuraikan, maka dapat dibuat beberapa kesimpulan sebagai berikut :

1. hasil evaluasi yang dilakukan dengan menggunakan pengujian usability, dapat diambil kesimpulan bahwa tingkat usability dari aspek Learnibilty 4,68, Efficiency 4,46, Memorabilty 4,64, Error 3,34 Satisfaction 3,74 maka dari keseluruhan variable ratarata diatas 3 atau ketergunaan aplikasi siskohat dinyatakan sangat baik.

\section{Referensi}

A.Hikmaturokhman dan A.Purwanto (dalam Ulfa,Maria dan Muzakir). Analisis Kinerja Packet Filtering Berbasis Mikrotik Routerboard Pada Sistem Keamanan Jaringan.Simetris: Jurnal Teknik Mesin, Elektro dan Ilmu Komputer 10.1 (2019): 15-20.

Aden Rosadi, 2011 Sejarah, Perkembangan dan Pemikiran Pengelola Ibadah Haji di Indonesia. CV. Arvino Raya. 
Anonymous. 1998. International Standard-ISO 9241-11. Switzerland Internet central@iso.ch

Antoni, D., \& Akbar, M. (2019). E-supply chain management value concept for the palm oil industry. Jurnal Sistem Informasi, 15(2), 15-29.

Antoni, D., Fikari, D., \& Akbar, M. (2018). The readiness of palm oil industry in enterprise resource planning. Telkomnika, 16(6), 2692-2702.

Antoni, D., Herdiansyah, M. I., Akbar, M., \& Sumitro, A. (2021). Pengembangan Infrastruktur Jaringan Untuk Meningkatkan Pelayanan Publik di Kota Palembang. JURNAL MEDIA INFORMATIKA BUDIDARMA, 5(4), 1652-1659.

Antoni, D., Jie, F., \& Abareshi, A. (2020). Critical factors in information technology capability for enhancing firm's environmental performance: case of Indonesian ICT sector. International Journal of Agile Systems and Management, 13(2), 159-181.

Aulia, M. B., Saputra, M. C. and Pinandito, A. (2016) 'Analisis Usability Pada Website Universitas Brawijaya Dengan Heuristic Evaluation’, 3(3).

Brooke, John. (1986). SUS-A quick and dirty usability scale. Usability evaluation in industry 189 , no. $194: 4-7$

Brooke, John. (1986). SUS-A quick and dirty usability scale. Usability evaluation in industry 189 , no. $194: 4-7$

Fahham, A. M. (2015). Penyelenggaraan Ibadah Haji: Masalah dan Penanganannya. Kajian: Menjembatani Teori dan Persoalan Masyarakat dalam Perumusan Kebijakan, 20 (3), 201-218.

Fauzi, F., Dencik, A. B., \& Asiati, D. I. (2019). Metodologi Penelitian untuk manajemen dan akuntansi. Jakarta: Salemba Empat.

Jogiyanto, 2005. Analis \& Desain. Andi offset: Yogyakarta.

Kristanto, Andi. 2008. Perancangan Sistem Informasi dan Aplikasinya. Yogyakarta: Gava Media.

Kristanto, Andi. 2008. Perancangan Sistem Informasi dan Aplikasinya. Yogyakarta: Gava Media.

Krug, Steve, (2006), Don't Make Me Think! A Common Sense Approach to Web Usability, New Riders, California.

Mutmainnah. (2011). Implementasi Sistem Informasi dan Komputerisasi Haji Terpadu (SISKOHAT) pada Kementerian Agama Republik Indonesia. [Skripsi].

Nielsen, J. 2012. Usability 101: Introduction to Usability. [online] Tersedia di<https://www.nngroup.com/articles/usability-101-introduction-to-usability/>

Sauro, Jeff. (2011). Measuring Usability with the System Usability Scale (SUS). Tersedia: https://measuringu.com/sus/.

Sutabri, Tata. 2004. Sistem Informasi Akuntansi. Yogyakarta : Andi

Sutabri, Tata. 2005. Sistem Informasi Manajemen. Yogyakarta : Andi.

Sutabri, Tata. 2005. Sistem Informasi Manajemen. Yogyakarta: Andi Offset. 
Thomas, N. (2015) How To Use The System Usability Scale (SUS) To Evaluate The Usability Of Your Website, July 13, 2015. Available at: https://usabilitygeek .com/howto-use-the-system-usability-scale-sus-to-evaluate-the-usability-of-your-website/.

\section{Copyrights}

Copyright for this article is retained by the author(s), with first publication rights granted to the journal.

This is an open-access article distributed under the terms and conditions of the Creative Commons Attribution license (http://creativecommons.org/licenses/by/4.0/) 